E-ISSN: 2808-5361

http://e-journal.fkmumj.ac.id/
Proceeding The First

Muhammadiyah

Internasional- Public Health

and Medicine Conference

\title{
Antioxidant Activity Test Of Endophyte Fungi Extract From Kayu Jawa (Lannea coromandelica (Houtt.) Merr.) Roots Using Dpph Method (2,2- Diphenyl-1-1-Picrylhydrazyl)
}

${ }^{1}$ Tharlis Dian Syah Lubis, ${ }^{2}$ Ismatuz Zulfa

${ }^{1}$ Master Program of Public Health, Faculty of Public Health, Muhammadiyah University of Jakarta K.H. Ahmad Dahlan State, Cirendeu, Districts East Ciputat, South Tangerang City, Banten 15419

${ }^{2}$ Pharmacy Study Program, Faculty of Health Sciences, Syarif Hidayatullah State Islamic University Jakarta

Ir. H. Djuanda State, No.95, Ciputat, South Tangerang, Banten 15412

E-mail: tdslubis@gmail.com

\begin{abstract}
Indonesia has abundant and diverse natural resources from land and sea. These biological natural resources can be explored as medicinal materials well-sourced from plants, animals, or microorganisms. Endophytic fungus is a microbial resource that grows in plant tissues that can produce compounds that have the same efficacy as the host plant. Zulfa (2016) has successfully isolated the endophytic fungi from kayu Jawa (Lannea coromandelica) roots and extracted the extracts with given code A11KA, A11KB, A12KC, A12KD, A21KK, A22KJ, AP12A, AP13L, $A P 21 C$, and AP32I. Other activities in these extracts besides antibacterial activity need to be tested. So this study was conducted to test the antioxidant activity of the extract with the DPPH method and used vitamin $C$ positive control. Fifteen samples were obtained in this study, they

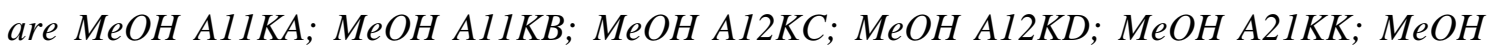
AP12A; MeOH AP13L; MeOH AP12C; MeOH AP321; EA A11KA; EA A12KC; EA AP321; EA AP12A; EA AP13L; EA A22KJ from methanol fractions (MeOH) and ethyl acetate fraction (EA). The antioxidant activity test results showed that only six samples were potential as antioxidants. Value of AAI (Antioxidant Activity Index) EA A12KC; EA A11KA; MeOH A11KA; EA AP321; $\mathrm{MeOH} A P 21 C$; EA A22KJ and vitamin C are 2.27 (very strong), 2.07 (very strong), 1.78 (strong), 1.19 (strong), 0.81 (medium), 0.53 (medium) and 11.67 (very strong) respectively. The result of antioxidant analysis using GC-MS showed only EA A11KA showing the presence of phenol compound, the largest phenol compound in this sample was phenol, 2,4-bis (1,1dimethyl ethyl).
\end{abstract}

Keywords: AAI (Antioxidant Activity Index), DPPH, endophytic fungi extract, Jawa wood (Lannea coromandelica (Houtt.) Merr.). 
E-ISSN: 2808-5361

http://e-journal.fkmumj.ac.id/
Proceeding The First

Muhammadiyah

Internasional- Public Health

and Medicine Conference

\section{INTRODUCTION}

Indonesia is a country rich in biodiversity. This abundant natural wealth is a blessing from Allah SWT. Antioxidants are compounds that can resist the occurrence of rancidity and inhibit oxidation reactions in materials containing fats or oils. (1) In addition, antioxidants are compounds that can inhibit reactive oxygen species / reactive nitrogen species and also free radicals so that antioxidants can prevent diseases associated with free radicals such as carcinogenesis, cardiovascular and aging. (2) The human body does not have an excessive amount of antioxidant reserves, so if there is excessive free radical exposure, the body needs exogenous antioxidants. (3)

Javanese wood (Lannea coromandelica) is one of the traditional medicinal plants used by people in South Sulawesi, because of its properties which are believed to be very effective for treating internal and external wounds such as vomiting blood and accelerating wound healing. Based on phytochemical studies, the bark of the Kayu Jawa plant has been reported to contain compounds of carbohydrates, steroids, alkaloids, cardiac glycosides, terpenoids, tannins, and flavonoids..(4) Several pharmacological studies have also been reported by researchers from India and Bangladesh that the methanol extract of the bark of the Javanese wood has biological activities such as antibacterial, antioxidant, analgesic., hypotensive activity, wound healing activity. (5)The data obtained from the chemical screening of Prawirodiharjo and Manik et al showed that the bark of the Javanese wood contains flavonoid compounds, saponins, and tannins. It has been reported that certain saponins and flavonoids can stabilize lysosomal membranes both in vivo and in vitro, while tannins and saponins can bind cations, thereby stabilizing erythrocyte membranes and other biological macromolecules. Phytochemical screening results Ethanol extract from wood roots also contains alkaloids, carbohydrates, flavonoids, triterpenoids, steroids, tannins, glycosides, saponins, and proteins. (6)

Endophytic molds are molds that live in plant tissues and can form colonies in plant tissues without harming the host plant. Endophytic molds can produce the same metabolites as their host plants. (7). Each higher plant can contain several endophytic microbes. Endophytic microbes are microorganisms that live in healthy plant cells and help the host plant to produce secondary metabolites. (8). Therefore, the metabolites produced by endophytes often have the same activity as the host plant. A small number of endophytes can also help the host plant in adapting to its environment. (9)

The latest research conducted by Zulfa (2016) has succeeded in isolating the endophytic mold of Javanese wood roots and carrying out extractions so that the extract is obtained with code A11KA, A11KB, A12KC, A12KD, A21KK, A22KJ, AP12A, AP13L, AP21C, and AP32I. 
E-ISSN: 2808-5361

http://e-journal.fkmumj.ac.id/
Proceeding The First

Muhammadiyah

Internasional- Public Health

and Medicine Conference

Of these 10 extracts, it is necessary to test for other activities other than antibacterial activity. The antioxidant activity was tested using the DPPH (1,1-Diphenyl-2-picrylhydrazil) method. The DPPH method provides information on the reactivity of the tested compound with a stable radical. DPPH gives strong absorption at a wavelength of $517 \mathrm{~nm}$ with a dark purple color. This research is expected to add new knowledge about the endophytic extract of Javanese wood roots as a new source of natural antioxidants so that it can save test materials and can be an effort to explore Indonesia's natural wealth without exploiting its biodiversity (10).

\section{METHODS}

The antioxidant activity test was carried out in vitro using the DPPH method. DPPH (2,2 diphenyl-1-picrihydrazyl) is a radical compound that is stable. DPPH is used to determine antioxidant activity through its ability to scavenge free radicals. Antioxidant activity is measured based on the electron transfer carried out by antioxidants. Initially, DPPH which is dark purple gives absorption at a wavelength of $517 \mathrm{~nm}$ but after being reduced, DPPH will turn into a diphenyl picryl hydrazine compound whose color will gradually fade to yellow, and the absorption value will be proportional to the number of electrons received. While the antioxidant comparison used is Vitamin C, the compound has good free radical inhibitory activity. Vitamin $\mathrm{C}$ has 4 hydroxyl groups that can react directly to donate one electron to form semihydroascorbate compounds that are unreactive (11). The next step is a disproportionate reaction of semihydroascorbate compounds to form dehydroascorbate which is then degraded to oxalic acid and threonic acid. (12)

\section{RESULTS AND DISCUSSION}

Based on the results that have been obtained in this research.

\section{Results of Phytochemical Screening of Javanese Wood Root Endophytic Extracts from the Ethyl Acetate Fraction}

Phytochemical screening was carried out to identify the content of secondary metabolites extracted in the ethyl acetate fraction of Javanese wood roots so that secondary metabolites could potentially have antioxidant activity. The compounds analyzed included alkaloids, flavonoids, saponins, tannins, phenols, steroids, and glycosides. The results of phytochemical screening carried out on the extract Javanese wood root endophytic from ethyl acetate fraction (EA) showed that all extracts contained secondary metabolite compounds including flavonoids, saponins, phenols, and tannins. 
Table 1. Results of Phytochemical Screening of Javanese Wood Root Endophytic Extracts from the Ethyl Acetate Fraction

\begin{tabular}{|c|c|c|c|c|c|c|}
\hline \multirow{2}{*}{$\begin{array}{c}\text { Test } \\
\text { Compound }\end{array}$} & \multicolumn{6}{|c|}{ RESULTS } \\
\hline & $\begin{array}{c}\text { EA } \\
\text { A12KC }\end{array}$ & $\begin{array}{c}\text { EA } \\
\text { A11KA }\end{array}$ & $\begin{array}{c}\text { EA } \\
\text { AP321 }\end{array}$ & $\begin{array}{c}\text { EA } \\
\text { AP13L }\end{array}$ & $\begin{array}{c}\text { EA } \\
\text { AP12A }\end{array}$ & $\begin{array}{c}\text { EA } \\
\text { A22KJ }\end{array}$ \\
\hline Alkaloids & - & - & - & - & - & - \\
\hline Flavonoids & + & + & + & + & + & + \\
\hline Saponins & + & + & + & + & + & + \\
\hline Glycoside & - & - & - & - & - & - \\
\hline Triterpenoids & - & - & - & - & - & - \\
\hline Phenol & + & + & + & + & + & + \\
\hline Tannins & + & + & + & + & + & + \\
\hline
\end{tabular}

Phytochemical Screening Java Wood Plant Root Endophytic Extract Methanol Fraction (MeOH)

Phytochemical screening was carried out to identify the content of secondary metabolites extracted in the methanol fraction of Javanese wood roots so that secondary metabolites could potentially have antioxidant activity. The compounds analyzed included alkaloids, flavonoids, saponins, tannins, phenols, steroids, and glycosides. On extract Endophytic root of Java wood from the methanol $(\mathrm{MeOH})$ fraction showed the content of secondary metabolites, namely flavonoids, saponins, glycosides, phenols, and tannins. Generally, the secondary metabolites obtained are polar so that they are extracted in the solvent used is methanol. The secondary metabolites found in plants are usually alkaloids, flavonoids, saponins, quinones, tannins, and steroids/triterpenoids. These natural antioxidants are usually found in fruits, vegetables, and woody plants. (13)

Table 2. Results of Phytochemical Screening of Javanese Wood Root Endophytic Extracts from the Mertanol Fraction

\begin{tabular}{ccccc}
\hline \multirow{2}{*}{ Test } & \multicolumn{5}{c}{ RESULTS } \\
\cline { 2 - 5 } Compound & MeOH & MeOH & MeOH & MeOH \\
& A11KA & A12KC & AP21C & AP321 \\
\hline Alkaloids & - & - & - & - \\
\hline Flavonoids & + & + & + & + \\
\hline Saponins & + & + & + & + \\
\hline Glycoside & + & + & + & + \\
\hline Triterpenoids & - & - & - & - \\
\hline Phenol & + & + & + & + \\
\hline Tannins & + & + & + & + \\
\hline
\end{tabular}

Table 3. Results of Phytochemical Screening of Javanese Wood Root Endophytic Extracts from the Mertanol Fraction Endophytic Extracts from the Mertanol Fraction 


\begin{tabular}{cccccc}
\hline & MeOH & MeOH & MeOH & MeOH & MeOH \\
& A21KK & A12KD & A11KB & AP13L & AP12A \\
\hline Alkaloids & - & - & - & - & - \\
\hline Flavonoids & + & + & + & + & + \\
\hline Saponins & + & + & + & + & + \\
\hline Glycoside & + & + & + & + & + \\
\hline Triterpenoids & - & - & - & - & - \\
\hline Phenol & + & + & + & + & + \\
\hline Tannins & + & + & + & + & + \\
\hline
\end{tabular}

The results of the phytochemical screening of both ethyl acetate (EA) and methanol $(\mathrm{MeOH})$ fractions showed that the secondary metabolites identified in the two fractions were flavonoids, saponins, phenols, and tannins. These secondary metabolites are natural antioxidant compounds.

Qualitative Antioxidant Testing with Thin Layer Chromatography (TLC) Method (14)

Java wood root endophytic extract was spotted on a TLC plate using a capillary tube.

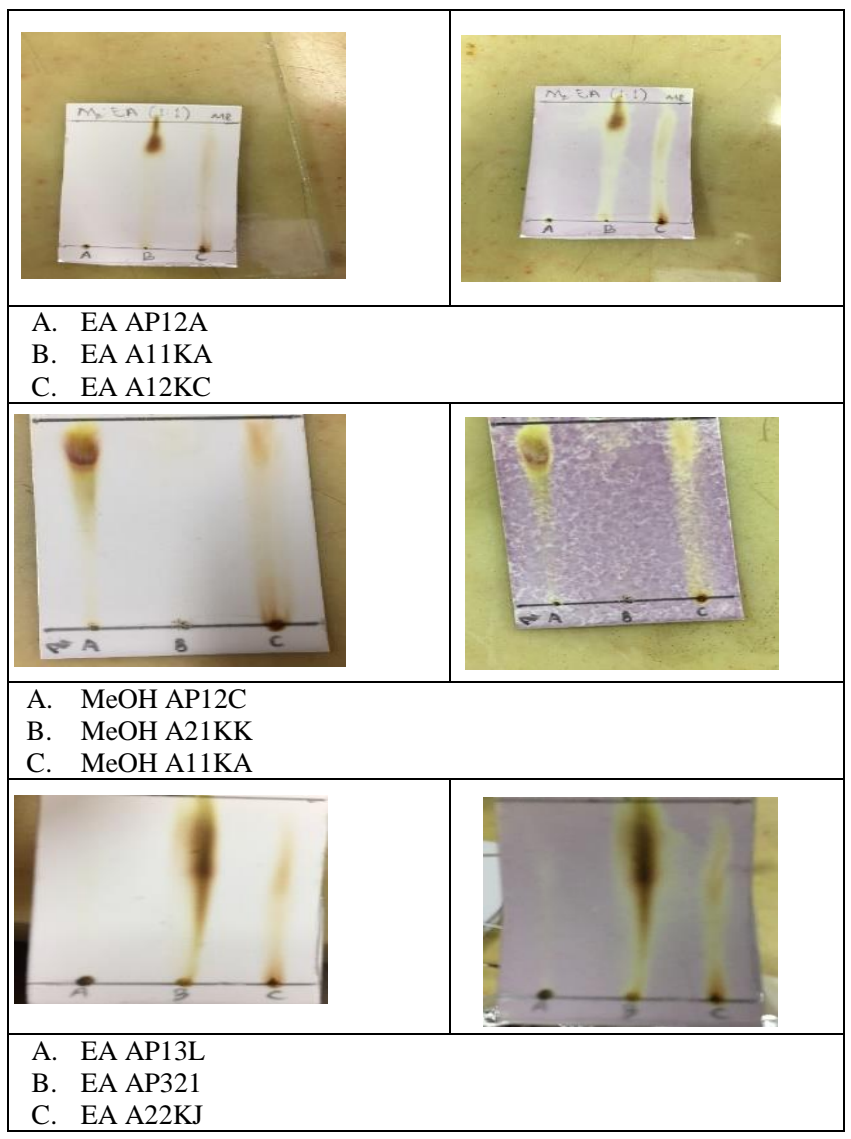


Proceeding The First Muhammadiyah Internasional- Public Health and Medicine Conference

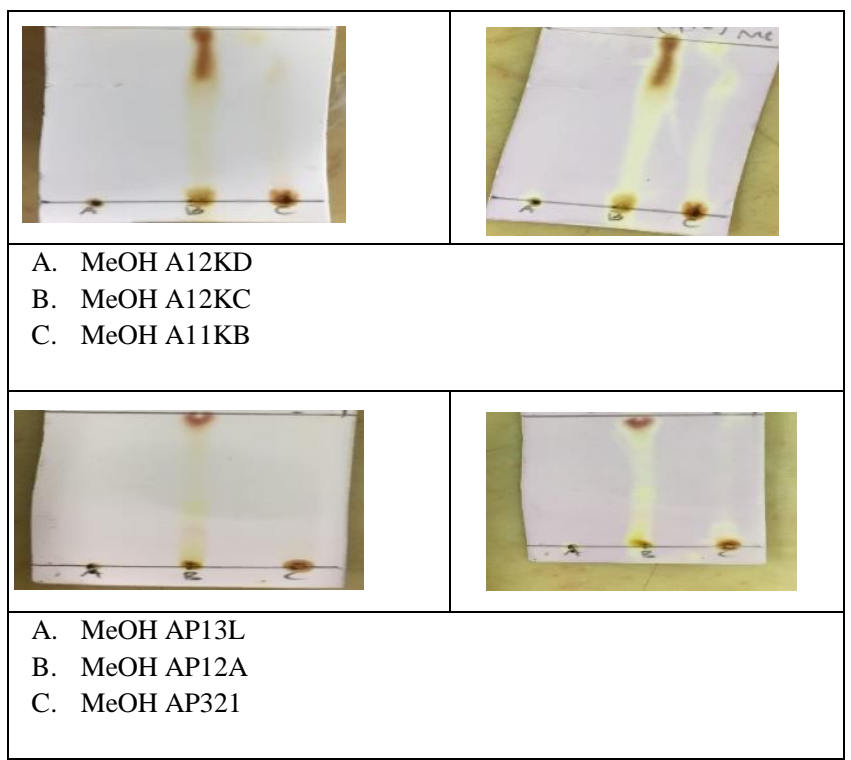

Figure 1. The results of qualitative antioxidant testing using the Thin Layer Chromatography (TLC) method

The elution process was carried out by inserting the TLC plate into a chamber containing the eluent and saturating it. The eluent is allowed to propagate until it reaches the previously marked plate boundary. After completion, the TLC plate was removed from the chamber. The TLC plate was then dried and sprayed with $0.1 \mathrm{mM}$ DPPH solution. The spots on the TLC plate that have antioxidant activity will turn white and yellow on a purple background. (15)

\section{Quantitative Antioxidant Activity Test}

Table 4. Results of Antioxidant Activity Test of Javanese Wood Root Endophytic Extract from EA A12KC

\begin{tabular}{|c|c|c|c|}
\hline $\begin{array}{c}\text { Concentration } \\
\text { (ppm) }\end{array}$ & $\begin{array}{c}\text { Absorbance } \\
\text { Average }\end{array}$ & $\begin{array}{l}\text { IC50 } \\
(\mathbf{p p m})\end{array}$ & AAI \\
\hline 06.25 & 0.178472 & \multirow{5}{*}{17.48} & \\
\hline 12.05 & 0.163194 & & 02.27 \\
\hline 25 & 0.134028 & & $(\mathrm{AAI}>2.0$ \\
\hline 50 & 0.082639 & & or Very \\
\hline 100 & 0.011 & & Strong) \\
\hline DPPH form & 0.303472 & - & - \\
\hline
\end{tabular}

Test Quantitative testing of antioxidant activity was carried out using the DPPH method (2,2-diphenyl-1-picrylhydrazyl). The choice of using this method is because it is a simple, easy, fast, and sensitive method and only requires a small sample to evaluate the antioxidant activity 
of natural compounds. The following are the results of the quantitative antioxidant activity test.

Table 5. Results of Antioxidant Activity Test of Javanese Wood Root Endophytic Extract from EA A11KA

\begin{tabular}{|c|c|c|c|}
\hline $\begin{array}{c}\text { Concentration } \\
(\mathrm{ppm})\end{array}$ & $\begin{array}{c}\text { Absorbance } \\
\text { Average }\end{array}$ & $\begin{array}{l}\text { IC50 } \\
\text { (ppm) }\end{array}$ & AAI \\
\hline 06.25 & 0.196528 & \multirow{5}{*}{24.62} & \multirow{5}{*}{$\begin{array}{c}0.08333 \\
\text { (AAI }>1-2 \\
\text { Strong) }\end{array}$} \\
\hline 12.05 & 0.169444 & & \\
\hline 25 & 0.129861 & & \\
\hline 50 & 0.072 & & \\
\hline 100 & 0.098 & & \\
\hline DPPH form & 0.288194 & - & - \\
\hline
\end{tabular}

In this study, this A11KA EA sample may act as a pro-oxidant. It is proven by a decrease in absorbance at a concentration of $100 \mathrm{ppm}$, this is because at a concentration of 100 ppm this sample is already above the threshold for absorbing DPPH (Nurhidayah, 2009). This shows that the maximum concentration that can be used as an antioxidant is brought to 100 ppm, so the concentration series is changed to $10-50 \mathrm{ppm}$, which can be seen in the table below.

Table 6. Test Results of Antioxidant Activity of Javanese Wood Root Endophytic Extract from EA A11KA Concentration of 10-50 ppm

\begin{tabular}{cccc}
\hline Concentration (ppm) & Absorbance Average & $\begin{array}{c}\text { IC50 } \\
(\mathbf{p p m})\end{array}$ & AAI \\
\hline 06.25 & 0.18542 & & \\
\hline 12.05 & 0.16389 & 22.03 & $\begin{array}{c}0.097222222 \\
\text { AAI } 1-2 \\
\text { Strong }\end{array}$ \\
\hline 50 & 0.12986 & & \\
\hline 100 & 0.09167 & & Strong \\
\hline DPPH form & 0.008 & - & \\
\hline
\end{tabular}

Table 7. Test Results of Antioxidant Activity of Javanese Wood Root Endophytic Extract from MeOH A11KA

\begin{tabular}{|c|c|c|c|}
\hline Concentration (ppm) & Absorbance Average & $\begin{array}{c}\text { IC50 } \\
\text { (ppm) }\end{array}$ & AAI \\
\hline 10 & 0.24444 & \multirow{5}{*}{19.10} & \multirow{5}{*}{$\begin{array}{c}02.07 \\
\text { AAI }>2.0 \\
\text { or Very } \\
\text { Strong }\end{array}$} \\
\hline 20 & 0.19375 & & \\
\hline 30 & 0.14792 & & \\
\hline 40 & 0.10625 & & \\
\hline 50 & 0.07153 & & \\
\hline DPPH form & 0.4 & - & $\begin{array}{l}\text { Very } \\
\text { strong }\end{array}$ \\
\hline
\end{tabular}


Table 8. Results of Antioxidant Activity Test of Javanese Wood Root Endophytic Extract from EA AP321

\begin{tabular}{|c|c|c|c|}
\hline Concentration (ppm) & Absorbance Average & $\begin{array}{l}\text { IC50 } \\
(\mathrm{ppm})\end{array}$ & AAI \\
\hline 06.25 & 0.26319 & \multirow{5}{*}{33.16 .00} & \multirow{5}{*}{$\begin{array}{c}01.19 \\
\text { AAI 1-2 } \\
\text { Strong }\end{array}$} \\
\hline 12.05 & 0.24792 & & \\
\hline 25 & 0.22569 & & \\
\hline 50 & 0.16319 & & \\
\hline 100 & 0.012 & & \\
\hline DPPH form & 0.39375 & - & Strong \\
\hline
\end{tabular}

Table 9. Results of Antioxidant Activity Test of Javanese Wood Root Endophytic Extract from MeOH AP21C

\begin{tabular}{|c|c|c|c|}
\hline Concentration (ppm) & Absorbance Average & $\begin{array}{c}\text { IC50 } \\
(\mathrm{ppm})\end{array}$ & AAI \\
\hline 06.25 & 0.25833 & \multirow{5}{*}{49.09 .00} & \multirow{5}{*}{$\begin{array}{c}0.05625 \\
\text { AAI } 0.5-1 \\
\text { Medium }\end{array}$} \\
\hline 12.05 & 0.23542 & & \\
\hline 25 & 0.21111 & & \\
\hline 50 & 0.1375 & & \\
\hline 100 & 0.062 & & \\
\hline DPPH form & 0.30694 & - & Currently \\
\hline
\end{tabular}

Table 10. Results of Antioxidant Activity Test of Javanese Wood Root Endophytic Extract from EA A22KJ

\begin{tabular}{|c|c|c|c|}
\hline Concentration (ppm) & Absorbance Average & $\begin{array}{c}\text { IC50 } \\
(p p m)\end{array}$ & AAI \\
\hline 06.25 & 0.28611 & \multirow{5}{*}{74.77} & \multirow{5}{*}{$\begin{array}{c}00.53 \\
\text { AAI 0.5-1 } \\
\text { Medium }\end{array}$} \\
\hline 12.05 & 0.26181 & & \\
\hline 25 & 0.23472 & & \\
\hline 50 & 0.19861 & & \\
\hline 100 & 0.10972 & & \\
\hline DPPH form & 0.30694 & - & Currently \\
\hline
\end{tabular}

Table 11. Results of Antioxidant Activity Test of Javanese Wood Root Endophytic Extract from EA AP13L

\begin{tabular}{|c|c|c|c|}
\hline Concentration (ppm) & Absorbance Average & $\begin{array}{c}\text { IC50 } \\
(\mathrm{ppm}) \\
\end{array}$ & AAI \\
\hline 06.25 & 0.30764 & \multirow{5}{*}{80.89} & \multirow{5}{*}{$\begin{array}{c}00.49 \\
\text { AAI }<0.5 \\
\quad \text { Weak }\end{array}$} \\
\hline 12.05 & 0.29236 & & \\
\hline 25 & 0.27083 & & \\
\hline 50 & 0.24097 & & \\
\hline 100 & 0.17292 & & \\
\hline DPPH form & 0.39653 & - & Weak \\
\hline
\end{tabular}


Table 12. Results of Antioxidant Activity Test of Javanese Wood Root Endophytic Extract from $\mathrm{MeOH}$ $\mathrm{A} 12 \mathrm{KC}$

\begin{tabular}{|c|c|c|c|}
\hline Concentration (ppm) & Absorbance Average & $\begin{array}{c}\text { IC50 } \\
(\mathrm{ppm})\end{array}$ & AAI \\
\hline 06.25 & 0.27847 & \multirow{5}{*}{87.98} & \multirow{5}{*}{$\begin{array}{c}00.45 \\
\text { AAI }<0.5 \\
\text { Weak }\end{array}$} \\
\hline 12.05 & 0.27153 & & \\
\hline 25 & 0.24583 & & \\
\hline 50 & 0.20903 & & \\
\hline 100 & 0.13125 & & \\
\hline DPPH form & 0.28472 & - & Weak \\
\hline
\end{tabular}

Table 13. Test Results of Antioxidant Activity of Javanese Wood Root Endophytic Extract from $\mathrm{MeOH}$ A21KK

\begin{tabular}{|c|c|c|c|}
\hline Concentration (ppm) & Absorbance Average & $\begin{array}{c}\text { IC50 } \\
(\mathrm{ppm}) \\
\end{array}$ & AAI \\
\hline 06.25 & 0.30347 & \multirow{5}{*}{106.49 .00} & \multirow{5}{*}{$\begin{array}{c}00.37 \\
\text { AAI }<0.5 \\
\text { Weak }\end{array}$} \\
\hline 12.05 & 0.29722 & & \\
\hline 25 & 0.28681 & & \\
\hline 50 & 0.25556 & & \\
\hline 100 & 0.17917 & & \\
\hline DPPH form & 0.30556 & - & Weak \\
\hline
\end{tabular}

Table 14. Results of Antioxidant Activity Test of Javanese Wood Root Endophytic Extract from EA AP12A

\begin{tabular}{|c|c|c|c|}
\hline Concentration (ppm) & Absorbance Average & $\begin{array}{l}\text { IC50 } \\
(\mathrm{ppm})\end{array}$ & AAI \\
\hline 06.25 & 0.29306 & \multirow{5}{*}{107.13 .00} & \multirow{5}{*}{$\begin{array}{c}00.37 \\
\text { AAI }<0.5 \\
\text { Weak }\end{array}$} \\
\hline 12.05 & 0.28333 & & \\
\hline 25 & 0.26528 & & \\
\hline 50 & 0.22847 & & \\
\hline 100 & 0.16528 & & \\
\hline DPPH form & 0.30347 & - & Weak \\
\hline
\end{tabular}

Table 15. Results of Antioxidant Activity Test of Javanese Wood Root Endophytic Extract from $\mathrm{MeOH}$ A12KD

\begin{tabular}{cccc}
\hline Concentration (ppm) & Absorbance Average & $\begin{array}{c}\text { IC50 } \\
(\mathbf{p p m})\end{array}$ & AAI \\
\hline 06.25 & 0.27708 & & 00.34 \\
\cline { 1 - 3 } 12.05 & 0.27292 & & $\begin{array}{c}116.05 .00 \\
\text { AAI }<0.5 \\
\text { Weak }\end{array}$ \\
\hline 50 & 0.25208 & & Weak \\
\hline DPPH form & 0.22361 & - & Weak
\end{tabular}


Table 16. Results of Antioxidant Activity Test of Javanese Wood Root Endophytic Extract from $\mathrm{MeOH}$ $\mathrm{A} 12 \mathrm{~KB}$

\begin{tabular}{|c|c|c|c|}
\hline Concentration (ppm) & Absorbance Average & $\begin{array}{l}\text { IC50 } \\
(\mathrm{ppm})\end{array}$ & AAI \\
\hline 06.25 & 0.28056 & \multirow{5}{*}{143.59 .00} & \multirow{5}{*}{$\begin{array}{c}00.28 \\
\text { AAI }<0.5 \\
\quad \text { Weak }\end{array}$} \\
\hline 12.05 & 0.27708 & & \\
\hline 25 & 0.27292 & & \\
\hline 50 & 0.24583 & & \\
\hline 100 & 0.19306 & & \\
\hline DPPH form & 0.28542 & - & Weak \\
\hline
\end{tabular}

Table 17. Test Results of Antioxidant Activity of Javanese Wood Root Endophytic Extract from MeOH AP321

\begin{tabular}{|c|c|c|c|}
\hline Concentration (ppm) & Absorbance Average & $\begin{array}{c}\text { IC50 } \\
\text { (ppm) }\end{array}$ & AAI \\
\hline 06.25 & 0.27361 & \multirow{5}{*}{147.84} & \multirow{5}{*}{$\begin{array}{c}00.27 \\
\text { AAI }<0.5 \\
\text { Weak }\end{array}$} \\
\hline 12.05 & 0.26875 & & \\
\hline 25 & 0.25694 & & \\
\hline 50 & 0.22569 & & \\
\hline 100 & 0.19097 & & \\
\hline DPPH form & 0.28958 & - & Weak \\
\hline
\end{tabular}

Table 18. Results of Antioxidant Activity Test of Javanese Wood Root Endophytic Extract from $\mathrm{MeOH}$ AP13L

\begin{tabular}{|c|c|c|c|}
\hline Concentration (ppm) & Absorbance Average & $\begin{array}{c}\text { IC50 } \\
\text { (ppm) }\end{array}$ & AAI \\
\hline 06.25 & 0.28264 & \multirow{5}{*}{ 199.01.00 } & \multirow{5}{*}{$\begin{array}{c}00.20 \\
\text { AAI }<0.5 \\
\text { Weak }\end{array}$} \\
\hline 12.05 & 0.27778 & & \\
\hline 25 & 0.26875 & & \\
\hline 50 & 0.25486 & & \\
\hline 100 & 0.21597 & & \\
\hline DPPH form & 0.29514 & - & Weak \\
\hline
\end{tabular}

Table 19. Test Results of Antioxidant Activity of Javanese Wood Root Endophytic Extract from MeOH AP12A

\begin{tabular}{|c|c|c|c|}
\hline Concentration (ppm) & Absorbance Average & IC50 (ppm) & $\overline{\mathbf{A A I}}$ \\
\hline 06.25 & 0.27292 & \multirow{5}{*}{412.96} & \\
\hline 12.05 & 0.26944 & & 00.10 \\
\hline 25 & 0.26528 & & $\mathrm{AAI}<0.5$ \\
\hline 50 & 0.25764 & & Weak \\
\hline 100 & 0.24306 & & \\
\hline DPPH form & 0.29097 & - & Weak \\
\hline
\end{tabular}

Table 20. Vitamin C Antioxidant Activity Test Results

\begin{tabular}{cccc}
\hline Concentration $(\mathbf{p p m})$ & Absorbance Average & $\begin{array}{c}\text { IC50 } \\
(\mathbf{p p m})\end{array}$ & AAI \\
\hline 2 & 0.21528 & \multirow{2}{*}{03.39} & $\begin{array}{c}0.504861111 \\
\text { AAI }>2.0\end{array}$ \\
\hline 4 & 0.18472 & & AAn
\end{tabular}




\begin{tabular}{cccc}
\hline Concentration (ppm) & Absorbance Average & $\begin{array}{c}\text { IC50 } \\
(\mathbf{p p m})\end{array}$ & AAI \\
\hline 6 & 0.13958 & or Very \\
\hline 8 & 0.10069 & Strong \\
\hline 10 & 0.098 & \\
\hline 12 & 0.041 & \\
\hline DPPH form & 0.38194 & \\
\hline
\end{tabular}

IC value50defined as the concentration of the test compound that can reduce free radicals by as much as $50 \%$. The smaller the IC. value50the higher the free radical scavenging activity (17). IC value50 was obtained from the linear regression equation while the AAI (Antioxidant activity index) value was determined by comparing the DPPH concentration used in the test (ppm) with the IC value.50obtained from each extract. The AAI value needs to be known to classify the antioxidant properties of the extract. If the value of $\mathrm{AAI}<0.5$ is a weak antioxidant, $0.5<\mathrm{AAI}<1$ is moderate, $1<\mathrm{AAI}<2$ is strong, and $\mathrm{AAI}>2$ is strong (18). Quantitative testing of antioxidant activity consisted of 15 extracts, namely 6 from the ethyl acetate fraction (EA A12KC; EA A11KA; EA AP321; EA AP12A; EA AP13L, and EA A22KJ) while from the methanol fraction $(\mathrm{MeOH})$ there were 9 extracts $(\mathrm{MeOH} \mathrm{A} 11 \mathrm{~KB} ; \mathrm{MeOH} \mathrm{A} 12 \mathrm{KC} ; \mathrm{MeOH}$ A12KD; MeOH AP321; MeOH A21KK; MeOH AP21C; MeOH AP13L; MeOH AP12A; $\mathrm{MeOH}$ A111KA) along with Vitamin $\mathrm{C}$ control (synthetic) were carried out with various concentration series using the DPPH method, then the absorbance was measured by UV-Vis spectrophotometry.

A quantitative antioxidant test was carried out using a UV-Vis spectrophotometer. This quantitative test was carried out to determine the remaining absorbance of DPPH after adding an endophytic extract of Javanese wood roots. The decrease in the absorbance value of DPPH at a wavelength of $515 \mathrm{~nm}$ indicates that the compound has antioxidant activity (19). The decrease in DPPH absorbance was measured against the control, namely the absorbance of DPPH in methanol pro-analysis without an additional sample. The color change from purple to yellow indicates a decrease in DPPH absorbance. The amount of DPPH absorbance is inversely proportional to the concentration of the added extract.

The absorbance value obtained can then be calculated as the percentage value of DPPH radical inhibition (\% inhibition). Then obtained a linear regression curve and its equation, with concentration as the $\mathrm{x}$-axis and absorbance as the y-axis. IC value50 can be calculated from the previously obtained linear regression equation by replacing y with 50 in the equation. IC value50 is defined as the concentration of the test compound that can reduce free radicals by as much as $50 \%$. The smaller the IC. value50 the higher the free radical scavenging activity. 
The AAI (Antioxidant activity index) value was obtained by comparing the concentration of DPPH used in the test with the IC. value50 which is obtained. Quantitative testing of antioxidant activity of this Javanese root endophytic extract in as many as 15 samples, along with positive control of vitamin $\mathrm{C}$ was carried out with various concentration series using the DPPH method, then the absorbance was measured using UV-Vis spectrophotometry. The following table and diagram of the antioxidant activity test results from all samples.

Table 21. Antioxidant Activity Test Results of All Samples and Vitamin C

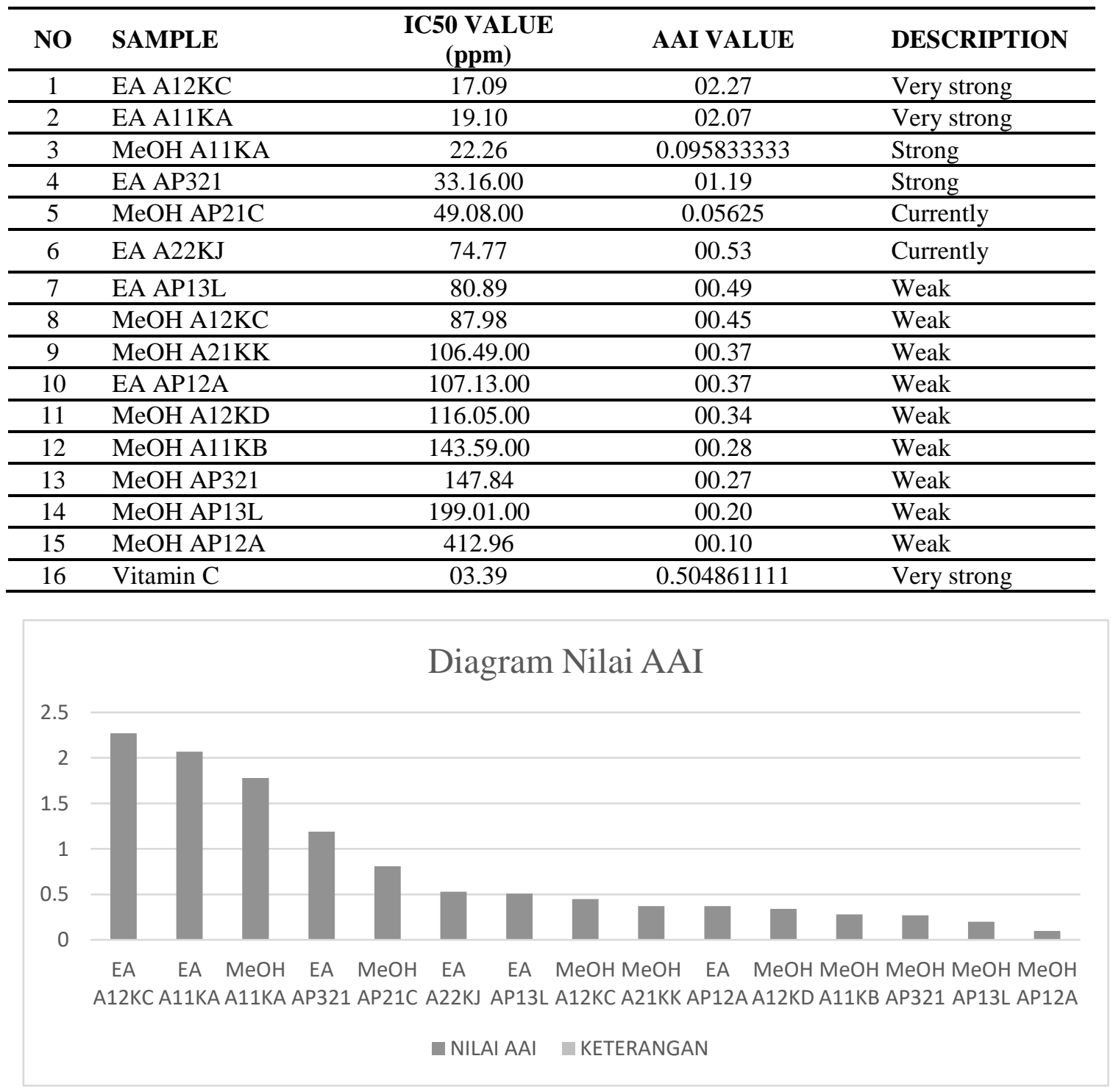

Diagram 1. Antioxidant Activity Test Results of All Samples Based on AAI Nilai Values 
E-ISSN: 2808-5361

http://e-journal.fkmumj.ac.id/
Proceeding The First

Muhammadiyah

Internasional- Public Health

and Medicine Conference

The results obtained from antioxidant testing using a UV-Vis spectrophotometer are that two samples have a very strong AAI, two samples have a strong AAI, two samples have a moderate AAI and nine samples have a weak AAI.

While IC50 and AAI vitamin C as comparison are $3.39 \mathrm{ppm}$ and 11.67, indicating that vitamin $\mathrm{C}$ has a very strong antioxidant activity because it has AAI above 2. and AAI of 17.09 ppm and 2.27 so that this sample is in the category of very strong antioxidant. This shows that vitamin $\mathrm{C}$ has a stronger antioxidant activity than the whole sample. The compounds contained in the Javanese root endophytic extract are an accumulation of polar, semi-polar, and non-polar compounds. When the extract is partitioned in stages, the synergistic function between the compounds will be reduced because the components contained in the extract have been separated.

The curve is obtained using linear regression in the Microsoft Excel 2013 data processing application. The y coefficient in the linear equation is 50 is the IC50 coefficient, while the $\mathrm{x}$ coefficient in this linear equation is the concentration of the extract to be sought, where $\mathrm{x}$ obtained is the amount of concentration required to can reduce $50 \%$ of DPPH radical activity. The value of R2 describes the linearity of concentration to \% inhibition. The value of $\mathrm{R} 2$ which is close to +1 (positive value) indicates that as the concentration of the extract increases, the antioxidant activity also increases. This is related to the number of secondary metabolites dissolved in the extract and has antioxidant activity.

\section{Antioxidant Analysis Using GC-MS}

In this study, the samples analyzed by gas chromatography were six samples, namely EA A12KC; EA A11KA; MeOH A11KA; EA AP321; MeOH AP21C, and EA A22KJ. The reason for choosing these six samples was because their antioxidant activity was categorized as very strong, strong, and moderate. Antioxidant compounds that can be analyzed by GC-MS are phenolic compounds because they are volatile compounds. Of the six samples, which showed the presence of phenolic compounds was the EA A11KA sample. The other samples did not show any phenolic compounds that could be analyzed by GC-MS. This is indicated by the absence of a class of phenolic compounds in the library data of the other five samples. This is presumably due to the presence of phenolic compounds in the other five samples in small concentrations (20). Therefore, further purification of the compound (isolation) is necessary to obtain pure compounds from the five samples. The largest phenolic compound detected in the EA A11KA sample was phenol,2,4-bis (1,1-dimethyl ethyl), with the chemical formula $\mathrm{C} 14 \mathrm{H} 22 \mathrm{O}$, molecular weight $(\mathrm{BM}) 206$, then had a similarity of $83 \%$ and a retention time of 18 minutes. 


\section{CONCLUSION AND SUGGESTIONS}

Based on the results obtained in this study, it can be concluded that fifteen endophytic extracts of Javanese wood roots tested using DPPH have various antioxidant activities. The sample that has the strongest antioxidant activity is the EA A12KC sample, with an AAI value of 2.27 so it is categorized as a very strong antioxidant. The results of the analysis using GC-MS found that the compounds that play a role in the antioxidant activity of the EA A11KA sample are phenolic group compounds with the namephenol,2,4-bis (1,1-dimethyl ethyl).

It is recommended that this research be continued to isolate bioactive compounds from samples that have very strong antioxidant activity.

\section{REFERENCES}

1. Matz, SA 1992. Bakery Technology and Engineering. Texas: Pan-Tech International, Inc. Matter. 31-32.

2. Halliwell, B, and Gutteridge, JMC 2000. Free Radicals in Biology and Medicine. Oxford University Press. New York. Scientific Biology Education, Educational Biology, Syiah Kuala University 4(1).

3. Clarkson, PM, and Thompson, HS 2000. Antioxidants: What Role Do They Play in Physical Activity and Health. Am J ClinNutr.72: 637-646.

4. Strobel, G. and B. Daisy. 2003. Bioprospecting for Microbial Endophytes and Their Natural Products. Microbiology and Molecular Biology. 67(4): 491-502.

5. Oyedapo OO, BA Akinpelu, KF Akinwunmi, MO Adeyinka and FO Sipeolu. 2010. Red blood cell membrane stabilizing potentials of extracts of Lantana camara and its fractions. International Journal of Plant Physiology and Biochemistry. 2(4); 46-51.

6. Alam Badrul, Hossain Sarowar, Habib Razibul, Rea Julia, and Islam Anwarul. 2012. Antioxidant and Analgesic Activities of Lannea coromandelica Linn. Bark Extract. International Journal of Pharmacology 8(4): 224-233. ISSN 1811-7775. Bangladesh.

7. Bhardwaj, Akanksha, et al. 2015. "Antimicrobial and Phytochemical Screening of Endophytic Fungi Isolated from Spikes of Pinus roxburghii”. iMedPub Journals Archives of Clinical Microbiology, Vol.6, No.3:1:1-9.

8. Prawirodiharjo, Erwin. 2014. Antioxidant Activity Test and Toxicity Test Of 70\% Ethanol Extract and Water Extract Of Javanese Bark. Thesis of UIN Syarif Hidayatullah.

9. Zulfa, Ismatutuz. 2016. Isolation and Antibacterial Activity Test of Root Endophytic Mold of Java Wood Plant (Lannea coromandelica (Houtt.) Merr.). Thesis of UIN Syarif Hidayatullah Jakarta. 
E-ISSN: 2808-5361 http://e-journal.fkmumj.ac.id/
Proceeding The First Muhammadiyah Internasional- Public Health and Medicine Conference

10. Strobel, G. and B. Daisy. 2003. Bioprospecting for Microbial Endophytes and Their Natural Products. Microbiology and Molecular Biology. 67(4): 491-502.

11. Syahrizal, D. 2008. Effect of vitamin C protection against transaminase enzymes and histopathological features of the liver of mice exposed to plumbun. The Thesis University of North Sumatra.

12. Musfiroh \& Syarief. 2012. Test of Free Radical Reduction Activity of Gold Nanoparticles with Various Concentrations as Antiaging Materials in Cosmetics. UNESA Journal of Chemistry Vol. 1 (2).

13. Isnindar, Wahyuono, S., \& Setyowati, EP 2011. Isolation and identification of antioxidant compounds from persimmon leaves (Diospyros kaki Thunb.) by DPPH method (2,2diphenyl-1-picrylhydrazil). Traditional Medicine Magazine. 16(3), 157-164. (February 23, 2016, 11:23).

14. Dachryanus. (2004). Spectroscopic Structural Analysis of Organic Compounds. Printing I. Padang: Andalas University Press. Matter. 39.

15. Croteau, R., Kutchan, TM and Lewis, NG 2000. Natural products (secondary metabolites. In BB Buchannan, W. Gruissem and RL Jones (eds), Biochemistry and Molecular Biology of Plants. American Society of Plant Physiologists, Rockville, MD.Pages: 1250-1318.

16. G. Zengin, A. Aktumsek, GO Guler, YS Cakmak, E. Yildiztugay. 2011. Antioxidant Properties of Methanolic Extract and Fatty acid Composition of Centaurea urvillei DC. subsp. Hayekiana Wagenitz. Natural Products 5, 123-132.

17. Molineux, P. 2004. The Use of The Stable Free Radical Diphenyl Picrylhydrazil (DPPH) for Estimating Antioxidant Activity. Songklankarin J. Sci. Technol., 26(2), 211-219.

18. Vasic, SM, Stefanovic, OD, Licina, BZ, Radojevic, ID, \& Comic, LR 2012. Biological Activities of Extracts from Cultivated Granadillapassifloraalata. EXCLI Journal. ISSN: 1611-2156.

19. Tiwari, Kumar, Kaur Mandeep, Kaur Gurpreet \& Kaur Harleem. 2011. Phytochemical Screening and Extraction: A Review. Internationale Pharmaceutica Science vol. 1: issues 1.

20. Rodoles, B., V. Salmeron, MV Martinez-Toledo and J. Gonzalez-Lopez. 1993. Production of vitamins by Azospirillum brazilense in chemically-defined media. Plants and Soil 153: 97-101. 
